\title{
Inventory and situation analysis of land resources for sustainable agriculture in Tamil Nadu
}

\author{
M. Chinnadurai ${ }^{1}$, S. Muraligopal, D. Suresh Kumar ${ }^{2}$, K. R. Karunakaran, K. Mani, K. Rajendran and \\ P. Asha Priyanka* \\ Department of Agricultural Economics, Tamil Nadu Agricultural University, Coimbatore (T.N.) India \\ (Email: tnau.asha53@gmail.com; ashapriyankap@gmail.com)
}

\begin{abstract}
Rapid land use change has taken place in Tamil Nadu over the past three to four decades due to accelerated cultivation, industrialization and urbanization. Growth of population influenced increased food requirements. In order to meet the basic requirements, the Government has planned to increase the irrigation facilities and the agricultural inputs, (High yielding varieties (HYV), seeds, agricultural implements etc.) to the farmers and also implement the interventional schemes and incentives to enhance farmer's income. Land use change may be examined by considering conversion of forest to crop and rangeland; losses of productive land through various factors; conversion of wetlands to agriculture and urban use: and conversion of other types of land to various human uses. The key to meet the present day challenges lies in the integrated management of the natural resources. Therefore, the knowledge of soil and land resources with respect to their spatial distribution, characteristics, potentials, limitations and their suitability for alternate land uses helps in formulating strategies to obtain higher productivity on sustained basis. With these views in mind an attempt has been made to study the spatial and temporal changes in the land use in Tamil Nadu.
\end{abstract}

Key Words : Land use pattern, Land resources inventory, Size-holding, Land degradation

View Point Article : Chinnadurai, M., Muraligopal, S., Kumar, D. Suresh, Karunakaran, K.R., Mani, K., Rajendran, K. and Priyanka, P. Asha (2019). Inventory and situation analysis of land resources for sustainable agriculture in Tamil Nadu. Internat. J. agric. Sci., 15 (1) : 48 55, DOI:10.15740/HAS/IJAS/15.1/48-55. Copyright@ 2019: Hind Agri-Horticultural Society.

Article History : Received : 25.10.2018; Revised : 22.11.2018; Accepted : 28.11.2018

\footnotetext{
* Author for correspondence:

${ }^{1}$ Centre for Agricultural and Rural Development Studies, Tamil Nadu Agricultural University, Coimbatore (T.N.) India

${ }^{2}$ Forest College and Research Institute (T.N.A.U.), Mettuppalyam (T.N.) India
} 